\title{
The structure and performance of US hotel real estate investment trusts
}

Received (in revised form): 26 February 2008

\section{Leonard A. Jackson}

teaches at the Rosen College of Hospitality Management in Orlando, Florida. Throughout his 20-year career, Dr Jackson has held senior managerial positions with leading hospitality enterprises. These include hotels, resorts, free-standing restaurants and a national airline. He received his doctorate degree from Oklahoma State University, USA, his master's from the University of Guelph, Canada, his bachelor's from Ryerson University, Canada and Associate of Arts degrees from George Brown College, Canada. Dr Jackson is a Certified Hospitality Accountant Executive (CHAE), Certified Hospitality Revenue Manager (CHRM), Certified Hospitality Technology Professional (CHTP) and Certified Hospitality Educator (CHE). He also earned a certificate in Revenue Management from Cornell University. Dr Jackson focuses his research in the areas of hotel development, lodging operations management, lodging real estate investment trusts, hospitality accounting, hospitality finance, information technology and asset management.

\begin{abstract}
Real estate investment trusts (REITs) have become a dominant force in the global equity investment marketplace. Modern REITs have their genesis in the US, where they emerged as investment vehicles during the early 1960 s. Since that time, the structure of the industry as a whole has changed and has become more efficient through the direct intervention of the US government. This paper outlines the present structure of US REITs and examines the performance of a relatively new subsector of the equity REIT market, hotel REITs. The study found that on average, hotel REITs performed better than the equity REIT portfolio. Hotel REITs were, however, riskier than other equity REITs. On a risk-adjusted basis, hotel REITs did not outperform the market portfolio.
\end{abstract}

\section{Keywords:}

hotel REITS, real estate investment performance, equity REIT

Journal of Retail and Leisure Property (2008) 7, 275-290. doi:10.1057/rlp.2008.19; published online 8 October 2008

Leonard A. Jackson Rosen College of Hospitality Management

University of Central Florida Orlando, FL

USA

Tel: +14079038154

Fax: +1 4079038105

E-mail: lajackso@mail.ucf.edu

\section{INTRODUCTION}

Real estate investment trusts (REITs) have become common in the global equity marketplace. In fact, since their introduction in the US in the 1960 s, the REIT structure has been adopted by several other countries, the most recent being Germany, the United Kingdom and France (Busching, 2007). In recent years, one burgeoning subsector of the US equity REIT market has been the lodging or hotel subsector. Although 
hotel REITs existed from as early as 1969, they did not appeal to investors as viable investment vehicles until their reintroduction to the public in 1993 (Burch and Taylor, 1998). Since then, hotel REITs have grown significantly in terms of both numbers - from two at the start of 1993, to a total of 11 at the end of 2007 - and capitalisation, from $\$ 100 \mathrm{~m}$ (Gu and Kim, 2003), to an estimated equity market capitalisation in excess of \$21bn (National Association of Real Estate Investment Trusts, Inc., 2008b). This growth has increased the cash flow into the lodging industry as well as changed the industry's ownership structure (Kim et al., 2002). It is interesting to note that the growth of this equity REIT subsector has occurred despite the fact that the proportion of unsystematic risk in the total risk of lodging REIT stocks was found to be 84 per cent (Kim et al., 2002), which exceeds the United States national average by 14 per cent (Gu and Kim, 1998). Hotel REITs also accounted for 9 per cent of the National Association of Real Estate Investment Trusts (NAREIT) equity index and 7 per cent of the overall REIT market (National Association of Real Estate Investment Trusts, Inc., 2008a). Hotel REITs are also estimated to represent 5 per cent of the overall United States hotel real estate market (Kim et al., 2002) (Figure 1).

The growth and emergence of hotel REITs as viable investment vehicles has followed an upward trend since 1993. This trend peaked in 2005 and 2006, when the hotel REIT sub-sector comprised 19 companies with market capitalisation exceeding $\$ 28 \mathrm{bn}$. This peak was followed by a sharp decline as the market corrected itself and weak or low-performing REITs exited the marketplace. Table 1 and Figures 2 and 3 illustrate the trend in hotel REIT numbers and market capitalisation.

$\mathrm{Gu}$ and Kim (2003) suggested that there are four factors that account for the growth of hotel REITs in terms of their absolute numbers as well as their market capitalisation. First, the Revenue Reconciliation Act of 1993 included legislations that eliminated tax hurdles, thereby making sizeable investments in equity REITs such as hotel REITs more attractive to institutional investors. The second reason suggested by $\mathrm{Gu}$ and $\mathrm{Kim}$ (2003) is the fact that the US hotel industry rebounded in 1992 from depressed occupancy rates brought on by the wanton real estate overbuilding in the previous decade, which caused the hotel industry's average occupancy level to decline from 70.6 per cent in 1980 to under 62 per cent by 1989 (Mullaney, 1998). In addition, the economic recession that affected the United States economy between 1991 and 1992 also caused occupancy and average room rates to decline. Once the recession was over, hotels became profitable and occupancy percentage and average daily rates rose steadily after 1993. In fact, between the end of 1992 and the end of 1996, demand for hotel rooms increased by more than 2.5 per cent annually. As a result of this improved performance, hotel REITs became the most financially rewarding investments in the REIT marketplace (Mullaney, 1998). Data obtained from Smith Travel Research (2007) supported this notion. Revenue per available room (RevPAR, a statistic that combines occupancy percentage and average daily rate) data shows that RevPAR has increased steadily since 1992 . The only exception was the period following the events of September 11 2001, when both 


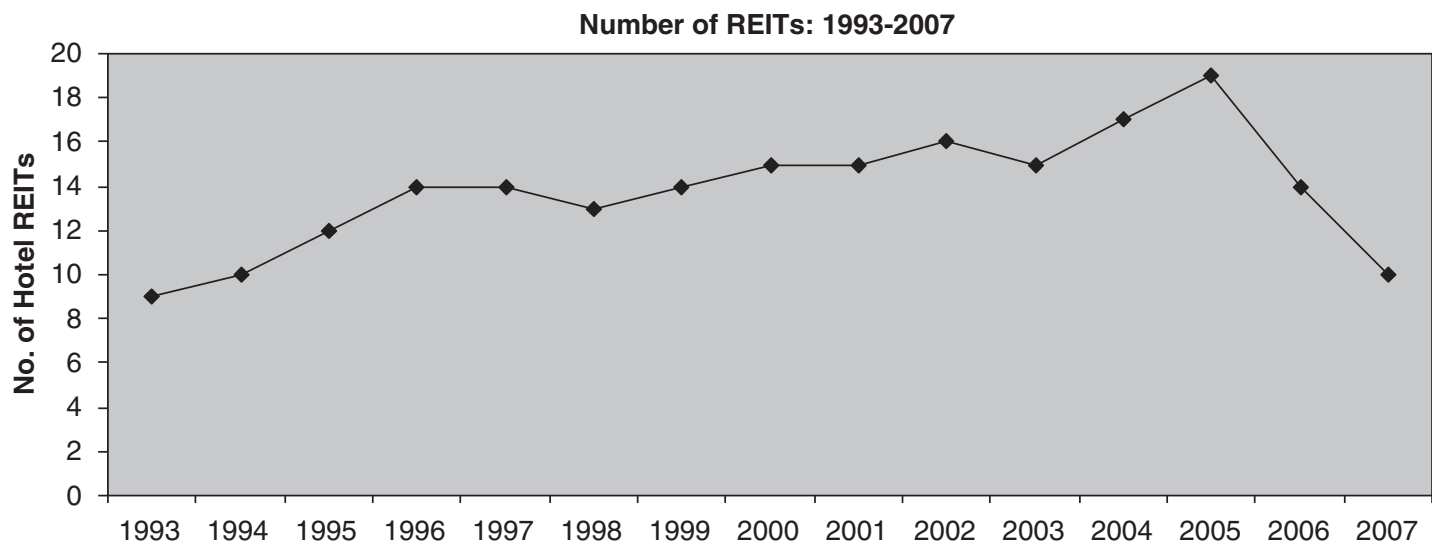

$\longrightarrow$ Number of REITs

Figure I: Hotel REITs Trend: 1993-2007

Source: National Association of Real Estate Investment Trusts (NAREIT)

Note: Number of REITs and market capitalisation are year end figures.

Table I: US REITs: numbers and capitalisation — 1993-2007

\begin{tabular}{lcc}
\hline Year & Number of REITs & Market capitalisation $\mathbf{( \$ m )}$ \\
\hline 1993 & 9 & 455,000 \\
1994 & 10 & 401,170 \\
1995 & 12 & $2,150,800$ \\
1996 & 14 & $5,396,200$ \\
1997 & 14 & $10,486,700$ \\
1998 & 13 & $12,597,000$ \\
1999 & 14 & $6,630,046$ \\
2000 & 15 & $7,524,610$ \\
2001 & 15 & $6,896,702$ \\
2002 & 16 & $7,789,033$ \\
2003 & 15 & $9,173,345$ \\
2004 & 17 & $14,510,924$ \\
2005 & 19 & $18,208,922$ \\
2006 & 14 & $28,905,770$ \\
2007 & 10 & $19,343,990$ \\
\hline
\end{tabular}

Source: NAREIT

Note: Number of REITs and market capitalisation are year end figures

occupancy and average daily rates, and consequently, RevPAR declined. Figure 3 highlights this trend.

The third reason cited was based on investment decision-making. According to $\mathrm{Gu}$ and Kim (2003), prudent investors viewed REITs as a way of combining financial resources and, in so doing, profiting from the benefits of commercial real estate investment. In the process, such investors inadvertently contributed to the growth of hotel REITs. Knight and Knight (1993) accentuated this point by arguing that hotel investors purchased ownership in hotel REITs with the intent that share values would continue to grow because of the constant flow of dividends and property value increases. Knight and Knight (1993) further argued that the notion also existed among hotel investors that as REITs became 


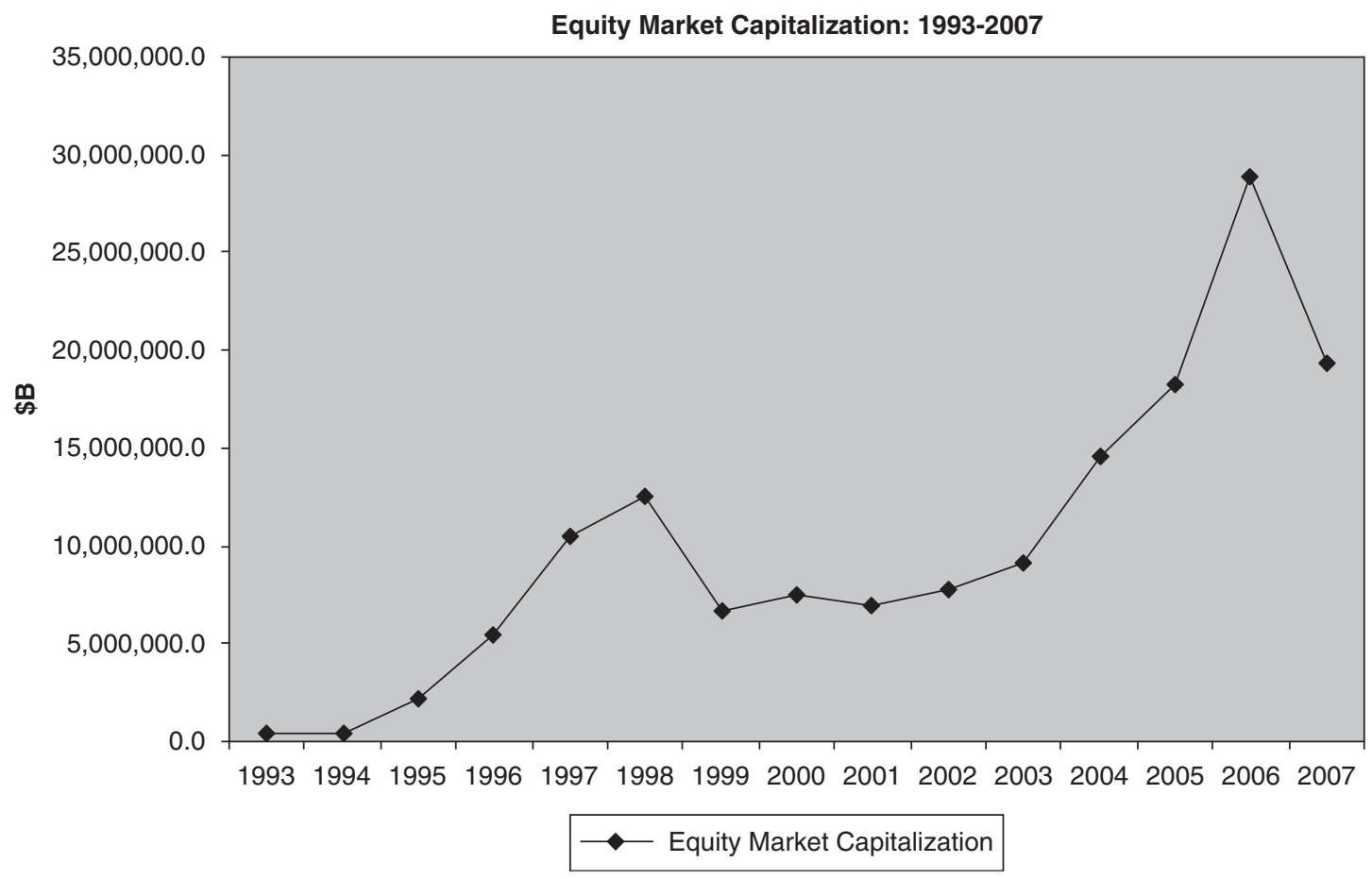

Figure 2: Hotel REIT Market Capitalisation trend: 1993-2007

Source: NAREIT

Note: Number of REITs and market capitalisation are year end figures.

profitable, the dividends generated could be reinvested in the company, thereby increasing each investor's stock value.

The final argument purported by Gu and Kim (2003) for the rapid growth of hotel REITs after 1993 was the fact that investors perceived REITs on the whole as providing investments that would offer inflationhedging abilities. This argument is supported by other researchers (Yobaccio et al., 1995; Chatrath and Liang, 1998) who also noted that REITs became attractive because they allow investors to diversify their portfolios (Grissom et al., 1978; Giliberto, 1990; Ori, 1995).

The purpose of this paper is to present an overview of the US hotel REIT industry's structure and to examine its performance relative to other equity REIT subsectors as well as against relevant market benchmarks. This examination is important since REITs as a whole have become the third largest asset class available to investors, behind bonds and stocks (Imperiale, 2002). In addition, with the wide array of REITs available in international markets, this sector requires closer examination.

\section{THE STRUCTURE OF US EQUITY REITS}

Hotel REITs are classified as equity REITs and hence, their structure will be similar to other equity REITs. US REITs exist in two broad categories: publicly traded REITs, which are those that are listed on an exchange or traded over the counter, and private REITs, which are neither listed nor traded publicly. Publicly traded REITs are further classified by their 


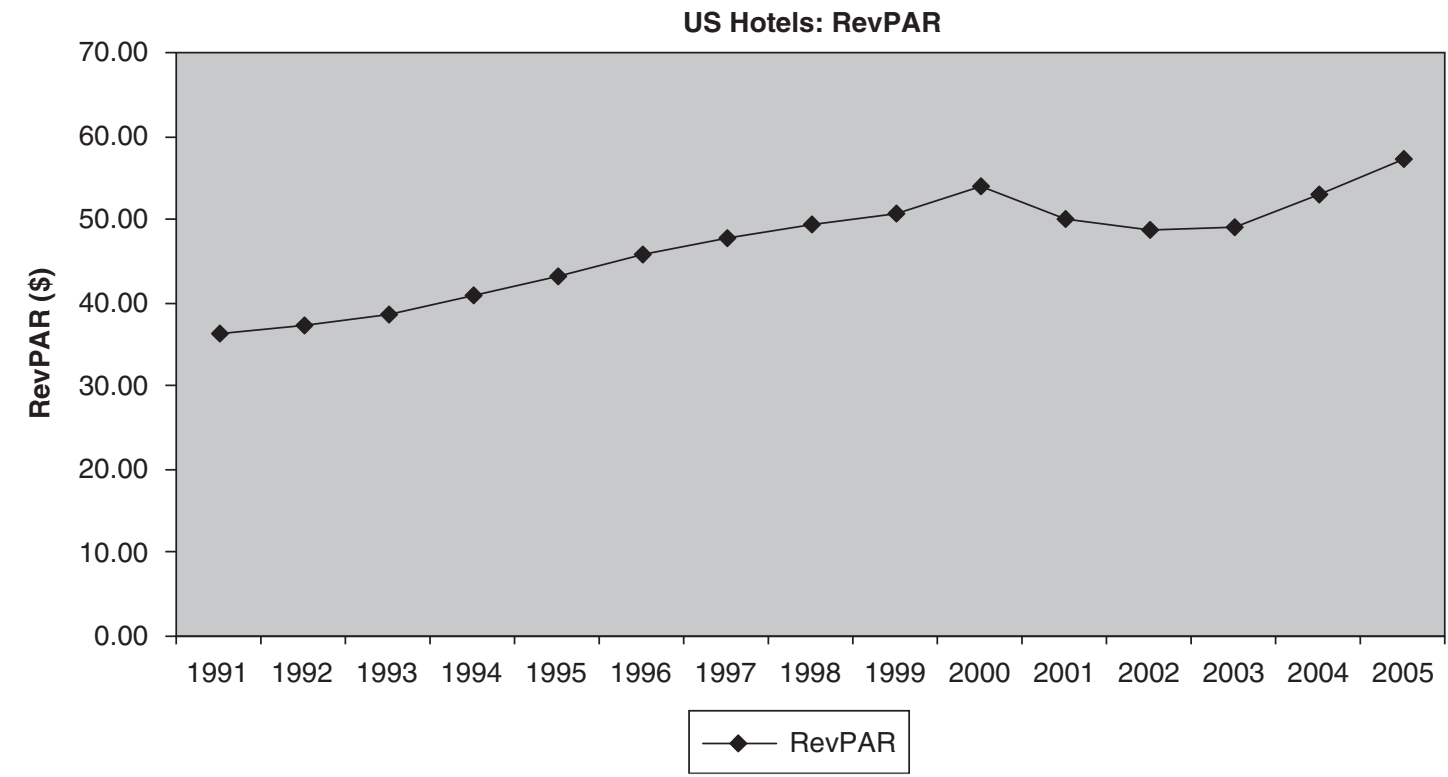

Figure 3: US hotels: RevPAR trend

Source: Smith Travel Research

investment sector as equity REITs, mortgage REITs and hybrid REITs. Equity REITs are those that acquire property interest, while mortgage REITs are those that purchase mortgage obligations and consequently become a creditor with mortgage liens given to priority equity holders. Mortgage REITs therefore own mortgage papers secured by the underlying real property. Hybrid REITs are those that combine the advantages of both mortgage and equity REITs.

In general, US REITs are companies that are publicly traded on the major US stock exchanges, namely the New York Stock Exchange (NYSE), American Stock Exchange (AMEX) or the National Association of Securities Dealers Automated Quotation (NASDAQ). Essentially, REITs are pools of properties and/or mortgages that are traded on one of these stock exchange markets. From the perspective of investors, REIT stocks represent a form of securitised real estate with claims on real property and/or mortgages (Chan et al., 2003). Conversely, from an ownership and management perspective, REITs are companies that are developed to own and manage income-producing real estate such as hotels, apartment complexes, shopping malls, golf courses, office buildings, self-storage centres, multifamily residences, manufactured housing, industrial properties and commercial net leases. Essentially, purchasers of REIT shares acquire assets that are either real property or mortgages.

Although most literature traces the origin of REITs to the passage of the Real Estate Investment Trust Act of 1960, their actual genesis can be traced back to the early 1900s when the Massachusetts Trust Company was formed by a group of New England (USA) entrepreneurs who wanted to profit from the burgeoning real estate industry. At the time, under Massachusetts law, corporations could only own real estate if the 
real estate was a key component of the business (Chan et al., 2003). Accordingly, the only way for the Massachusetts Trust Company to take advantage of the real estate market while at the same time adhering to the law was to develop the Massachusetts Trust Company, a REIT-like structure that legally allowed the corporation to invest in real estate, while at the same time enjoying benefits usually reserved for corporations such as the transferability of ownership shares, centralised management and limited liability (Chan et al., 2003).

Since its inception over a century ago, the US REIT industry has undergone several structural changes. In recent years, most of the changes and modifications of current tax laws that have impacted REITs have resulted in this investment vehicle becoming more efficient, competitive and attractive. This is because these changes have successfully removed some of the burdensome and confusing rules, regulations and restrictions that existed during the early years of REIT development. In addition, REITs have become more specialised, and many have chosen to focus their managerial skills and expertise on particular segments of the REIT industry, which maximises their efficiency.

As previously mentioned, today's US REITs are the direct result of changes in the United States tax laws, which have, over the past four decades, enabled REITs to become more viable and efficient as investment vehicles. Hence, US REITs are the direct creation of government legislations, and accordingly have evolved and grown as a result of changes in government legislations. As one traces the evolution and growth of the US modern REITs, it becomes clear that the industry has undergone several changes since they gained prominence in the 1960s. In essence, the growth and evolution of the industry can be divided into two stages: the 'old' REIT structure, which covered the period between 1960 and 1992, and the 'new' REIT structure, which covers the period between 1992 and 2008. The characteristics of each period are summarised in Table 2.

To maintain their status as REITs, these corporations are required by law to meet specific criteria established by the US tax code. These requirements relate directly to asset ownership, income generation, income distribution, and structure and ownership. The specifics of these criteria are summarised in Table 3.

Table 2: Summary of US REIT structural changes: 1960-2008

\begin{tabular}{ll}
\hline $\mathbf{1 9 6 0 - 1 9 9 2}$ & $\mathbf{1 9 9 2 - 2 0 0 8}$ \\
\hline $\begin{array}{l}\text { Passive investment (REIT could own the property but not engage } \\
\text { in is day to day operation or management) }\end{array}$ & Operating company \\
Externally administered & Self-administered \\
Institutional sponsors & Entrepreneur sponsors \\
Small management & Large management \\
Diversified portfolio & Specialised portfolio \\
Small capital base & Large capital base \\
Little analyst coverage & Extensive analyst coverage \\
\hline
\end{tabular}

Adapted: McMahan, J. (2006). The Handbook of Commercial Real Estate Investing (Ist edn.). McGraw-Hill Irwin, New York. 
Table 3: REIT legal requirements

\begin{tabular}{|c|c|}
\hline Requirement & Specific stipulation \\
\hline Asset ownership & $\begin{array}{l}\text { At least } 75 \text { per cent of the value of a REIT's asset must consist of real estate } \\
\text { assets, cash and government securities. This means that unlike C corporations, } \\
\text { REITs do not have the freedom to own or mange any type of assets. } \\
\text { No more than } 5 \text { per cent of the value of assets may comprise securities of any } \\
\text { one issuer if the securities are not includable under the } 75 \text { per cent test. } \\
\text { REITs cannot hold more than } 10 \text { per cent of the outstanding voting securities of } \\
\text { any one issuer if those securities are not includable under the } 75 \text { per cent test. } \\
\text { No more than } 20 \text { per cent of the REIT's assets can consist of the stocks of } \\
\text { taxable REIT securities. }\end{array}$ \\
\hline Income generation & $\begin{array}{l}\text { At least } 75 \text { per cent of gross income must be derived from rents, interest } \\
\text { on obligations secured by mortgages, gains from the sale of certain assets or } \\
\text { income attributable to investments in other REITs. } \\
\text { No more than } 30 \text { per cent of the REIT's gross income can be derived from } \\
\text { the sale or disposition of stock or securities held for less than six months or } \\
\text { real property held for less than four years except for property involuntarily } \\
\text { converted or foreclosed on. }\end{array}$ \\
\hline Income distribution & $\begin{array}{l}\text { At least } 90 \text { per cent of the REIT's taxable income (this was changed by the REIT } \\
\text { modernisation Act of } 1999 \text { from } 95 \text { pe rcent) must be distributed to } \\
\text { shareholders on an annual basis. This means that in order for REITs to expand, } \\
\text { they must seek external funding sources since they do not retain the majority of } \\
\text { their income (Beals and Arabia, 1998). }\end{array}$ \\
\hline REIT structure and ownership & $\begin{array}{l}\text { The REIT must be structured as a corporation, business trust or similar } \\
\text { association and must be taxable as a corporation. } \\
\text { Must be managed by a board of directors or trustees. } \\
\text { Be an investor in real estate, as opposed to a broker. } \\
\text { Shares in the REIT must be fully transferable and must be held by a minimum of } \\
100 \text { persons, with no more than five of these owning more than a combined } \\
50 \text { per cent of the trust's outstanding shares (the ' } 5 / 50 \text { rule'). } \\
\text { No more than } 50 \text { per cent of a REIT's shares may be held by five or fewer } \\
\text { individuals during the last half of a taxable year. }\end{array}$ \\
\hline
\end{tabular}

\section{REIT PERFORMANCE}

The performance of REITs can be examined from several perspectives. First, since the majority of REITs are publicly traded companies (Brueggerman and Fisher, 2005), their performance as business entities can be judged based on the performance of their stocks on the public stock exchanges. In this regard, studies pertaining to the performance of REITs have compared their performance against relevant market (market portfolios) benchmarks such as Standard and Poor's 500 (S\&P 500), NYSE and the NASDAQ composite. Such studies have yielded mixed results. In fact, empirical results relating to REIT performance over the past four decades have been at best mixed and lack consensus, especially as it pertains to the performance of REITs compared to relevant benchmarks.

In general, previous studies on REIT performance have arrived at one of four conclusions. Such research findings have indicated that when compared to relevant industry benchmarks on a risk-adjusted basis, REITs have either exceeded the market (Kuhle et al., 1986), underperformed the market,(Goebel and Kim, 1989; Wang et al., 1997), performed slightly better or about the same (Smith and Schulman, 1976; Smith, 1980; Glascock and Hughes, 1995), or performed slightly worse than, or no better than the market portfolio (Howe and Shilling, 1990; Han and Liang, 1995; Sanders, 1998). On a nominal return basis, when 
compared to relevant industry benchmarks, the trend remains the same. REITs have either underperformed the market (Glascock and Hughes, 1995; Chen and Peiser, 1999), displayed performance that was similar to the market (Wang et al., 1997), or performed about as well as, or no better than the market (Smith and Schulman, 1976).

Evidence from the literature also suggests that REITs perform differently over various time periods when compared to the stock market. For example, early studies on the long-run performance of REITs, conducted between the 1960s through the 1980s, suggest that REIT returns are similar to, or about the same as, those of the stock market (Smith and Schulman, 1976; Smith, 1980). More recent studies, however, do not support such findings, and instead portray REIT performance as less impressive than previously indicated. In fact, such studies have reported that REIT stocks either underperform the market (on a riskadjusted basis) or performed no better than the market (Goebel and Kim, 1989; Chan et al., 1990; Howe and Shilling, 1990; Martin and Cook, 1991; Glascock and Hughes, 1995; Wang et al., 1995, 1997; Chen and Peiser, 1999).

Other studies have examined the long-term qualitative aspects of the REIT markets such as appropriateness of REITs for certain investors (Bergsman, 2001; Haddock, 1998; Zell, 1998). Still other studies examined REIT performance for shorter periods. Brounen et al. (2000) examined equity REITs between the period 1993-1999 and found that REITs have a high market capitalisation. Some researchers have focused on the predictability and volatility of REIT returns versus returns from stocks, and the inflation hedging ability of REITs versus stock investments (Chatrath and Liang, 1998).

Previous research on REITs has also focused on the use of several different measures of investment performance. Several studies have focused primarily on the factors that affect or influence REIT returns using performance measures that are risk adjusted (Goebel and Kim, 1989; Howe and Shilling, 1990). Others have focused on comparing REIT performance to common stock and as well as real estate investments (Kuhle, 1987; Giliberto, 1990; Martin and Cook, 1991). Still, others have focused on applying models such as the Capital asset pricing model (CAPM) to ascertain the economics factors that affect REIT performance (Chan et al., 1990) while others have focused on the use of models such as the Jensen model to ascertain the relative performance of REITs.

Overall, researchers have presented divergent views on REIT performance, especially when compared to the stock market portfolio. On the one hand, REITs, most notably equity REITs, have been found to outperform the stock market portfolio (Kuhle, 1987; Sagalyn, 1990), while other findings suggest contrary viewpoints, and in fact have found that compared to the stock market portfolio, REITs have performed worse (Titman and Warga, 1986; Goebel and Kim, 1989).

Studies examining REIT performance have also examined such performance over the long term or over the short term. First and foremost are those that examined the performance of REITs over the short term (periods of less than ten years) and those conducted to examine 
performance over the long term (periods of ten or more years), the most comprehensive of which appeared in Han and Liang (1995). Using the traditional Jensen model, Han and Liang (1995) found that REIT performance was similar to the market during the period 1970-1993. Conversely, they also found that REIT performance was not stable over time. On the other hand, Li and Wang (1995) in their examination of equity REITs and mortgage REIT performance over a 20-year period found that REIT returns were more predictable than stock returns.

Still other researchers have argued that although quantitative analysis plays a significant role in the evaluation of REIT performance, the qualitative aspects of real estate such as property development should not be overlooked as these aspects have a direct effect on a REIT's performance. Brounen et al. (2000) argue that investors often attest that property development activities such as renovations will also increase the performance of REITs. This notion, however, could be fallacious since Brounen et al. (2000) found that although developing REITs yield higher returns than REITs that do not develop, when risk is taken into account there is no synergy or relationship between property development and REIT investment returns. In terms of lodging REITs Gordon and McCarthy (1998) found that the actual performance of lodging REITs on the stock market in terms of actual returns may not necessarily be connected to, or a reflection of, the performance of the physical assets themselves. Instead, they argued that there is a general disconnect between the performance of the real property and the performance of the investment as measured by returns. Consequently, they argued that REITs performance as measured by returns are less a function of the performance of the real property than on the management expertise of investment mangers.

\section{HOTEL REIT PERFORMANCE}

Despite having the highest return (income and long-term returns) volatility of all REIT property sectors (Mueller and Anikeeff, 2001; Imperiale, 2002), the overall performance of hotel REITs has been one of the best, compared to other REIT asset classes (Imperiale, 2002). In a previous study on the performance of hotel REITs, Kim et al. (2002) examined the performance of hotel REITs between the period 1993-1999 (short-term measure). In their study (2002), they applied the Jensen index (Jensen, 1968) of performance measure to examine the overall performance of hotel REITs relative to the market portfolio. Their (Kim et al., 2002) study findings revealed that overall hotel REIT performance was similar to that of the overall REIT portfolio as well as the market portfolio. When compared to other types of equity REITs however, hotel REITs' performance was found to be inferior to that of other types, namely office, industrial, residential and diversified REITs. Interestingly, the study found that hotel REITs performed similarly to healthcare and retail (Kim et al., 2002).

Other hotel REIT performance studies include Sarheim's (2006), who examined the performance of hotel REITs compared to C-Corporations 
and S\&P 500 during the period 2000-2005. This was a period during which the US hotel industry was affected by several significant events, namely a weak economy in 2000, the terrorist attack in 2001, the SARS epidemic and the Iraq war. Overall, hotel REITs were found to be resilient during this period. Other related hotel REIT performance studies include Kim et al. (2002), who examined the risk features of hotel REITs and $\mathrm{Gu}$ and Kim (2003), who examined the financial variables that affect hotels REIT's unsystematic risk.

Given the contentious and often conflicting findings regarding REIT performance, it is important that the performance of all REIT sectors is examined in relation to the overall market. This is especially important since REITs will continue to play a major role as an investment vehicle. In addition, it is crucial that the performance of hotel REITs is examined given the volatility and cyclical nature of the hotel industry. In this regard, it is the aim of this research to examine the long-term (period exceeding ten years) performance hotel REITs between the period January 1993 and December 2005. This period was chosen because it heralded the emergence of hotel REITs as viable investments. In addition, this period was a turbulent and volatile time for the US hotel industry, as the country was affected by geopolitical events (the Iraq wars), one-time events (September 11, 2001) as well as an economic recession. Hence, the examination period would indicate how well the US hotel REIT industry would 'stand up' and perform under adverse conditions. In this regard, performance was measured by how well hotel REITs performed during the period compared to a relevant market portfolio, S\&P 500. Several studies have used this portfolio as a benchmark against which investment performance can be measured (Han and Liang, 1995; Oppenheimer and Grissom, 1998; Kim et al., 2002). The study therefore attempted to address the following question: Do hotel REITs overperform or underperform the relevant market portfolio?

\section{METHODOLOGY}

\section{Data collection and data source}

The study utilised time series data obtained from the Center for Research in Security Prices (CRSP) database. Specifically, monthly REIT stock returns for the period January 1993-December 2005 were analysed. The CRSP has provided comprehensive historical US stock market data since 1962. The CRSP data files include common stocks that are traded on the NYSE, the AMEX, S\&P 500 and the NASDAQ and CRSP valueweighted and CRSP equally weighted indices. The CRSP stock files indices are provided in four frequencies: daily, monthly, quarterly and annually. Monthly data were utilised for this study.

Initially, a total of 403 REITs were extracted from the database, which included REITs that were currently trading as well as those that had exited the market. REITs that traded for less than 12 months and those with missing or incomplete data were removed from the sample. Mortgage and hybrid REITs were also removed from the sample. The final count was 297 equity REITS, which were further classified into their respective property 
subsectors (diversified, healthcare, self-storage, industrial, office, residential, retail, hotel, specialty or mixed). REITs were classified according to their last trading investment and property subsectors as reported by NAREIT. This classification was based on the 75 per cent classification rule, which classifies a company according to the percentage of assets invested in a specific subsector. According to this rule, if 75 per cent or more of a company's assets are invested in a specific sector, the company is classified as being in that sector. The subsector breakdown was 28 diversified, 16 healthcare, 26 industrial, 26 hotel, 5 mixed, 36 office, 57 residential, 70 retail, 22 self-storage and 11 specialty REITs.

Since the study was designed to determine whether or not hotel REITs overperformed or underperformed a relevant benchmark, the appropriate benchmarks had to be chosen. The benchmark selected for this study was S\&P 500 market weighted index. This index was chosen because it is commonly used as a benchmark against which to measure investment performance (Han and Liang, 1995; Oppenheimer and Grissom, 1998; Kim et al., 2002). In addition, several hotel REITs are included in S\&P 500. The benchmark data were also obtained from the CRSP database. It was also decided to use the monthly return on the three-month US Treasury Bill (90 days Treasury) as a proxy for the risk-free rate for this study. Several other studies (Han and Liang, 1995; Oppenheimer and Grissom, 1998; Kim et al., 2002) relating to the performance of REITs have used the three-month US Treasury Bill as a proxy for the risk-free rate. The risk-free data were obtained from the United States Federal Reserve website (http://www.federalreserve.gov/).

\section{Data analysis}

There are three common indices used for measuring risk-adjusted performance of stock portfolios: the Sharp index (Sharpe, 1966), the Treynor index (Treynor, 1965) and the Jensen index (Jensen, 1968). All three indices generally assume that the CAPM theory holds. This theory generally states that a portfolio's expected price is comprised of the risk-free rate plus the systematic risk multiplied by the market risk premium, which is the expected market return less the risk-free rate. The systematic risk is labelled Beta and is the covariance of the market return and the individual portfolio's return divided by the variance of the market return. The Sharp index and the Treynor index are both based on the ratio of return to risk. The Jensen index, however, attempts to measure the relative performance based on the security market line. The most common and widely used risk-adjusted performance measures are those based on Jensen's alpha (the Jensen index), which is generally used to measure whether or not a portfolio overperforms or underperforms compared to an established benchmark. Hence, this study utilised the Jensen index to ascertain whether or not hotel REITs overperformed or underperformed S\&P 500. Previous studies on hotel REIT performance have also utilised the Jensen index (Kim et al., 2002). Mathematically, the Jensen index canbe seen as

$$
\left(R_{i, t}-R_{f, t}\right)=\alpha_{i}+\beta_{i}\left(R_{m, t}-R_{f, t}\right)+\varepsilon_{i, t}
$$

where $R_{i, t}$ is the return on portfolio $i$ at time $t ; R_{f, t}$ is the return on the riskfree asset at time $t ; R_{m, t}$ is the market return at time $t ; \alpha_{i}$ is the Jensen 
index measure of performance on portfolio $i ; \beta_{i}$ is the systematic risk for portfolio $i$; and $\varepsilon_{i, t}$ is the random error with expected value equal to zero (ie $\mathrm{E}\left(\varepsilon_{i, t}\right)=0$ ).

The risk-free rate is essentially the return that an investor would expect to receive assuming that there was no risk involved in receiving it. In other words, the return was not subject to default risk, yield curve risk, inflation risk or any other risks affecting securities. As previously noted, for this study, it was decided to use the monthly return on the three-month US Treasury Bill as a proxy for the risk-free rate.

The $\alpha_{i}$ and $\beta_{i}$ in the Jensen index were estimated using the leastsquares regression procedure. This statistical method plots a line through the data that minimises the sum of the squared errors. For the regression, the market excess return was the independent variable and the REIT portfolio less the risk-free rate was the dependent variable. This means that $\alpha_{i}$ was the estimated excess return (or loss) on the REIT and $\beta_{i}$ was the estimate for the systematic risk on the REIT. To determine whether or not a given REIT portfolio overperformed or underperformed as compared to an established benchmark (or market portfolio), we simply need to determine whether $\alpha_{i}$ is statistically different from zero. To determine whether the REIT portfolio contributed more or less risk than the market portfolio, we need to determine whether $\beta_{i}$ is statistically different from 1 . In order to perform the calculations used in the study, several software programs were utilised. All statistics were performed using Microsoft Excel 2007 except for the Dubin Watson test statistics, which were calculated using SPSS Version 14.

\section{RESULTS AND DISCUSSION}

A series of nonrisk-adjusted descriptive statistics were performed to determine whether hotel REITs performed better or worse than other equity REITs. Table 4 provides a summary of these results. The results indicated that during the study period, hotel REITs had an average monthly return of 0.89 per cent, which is only slightly higher than the 0.81 per cent return that the equity REIT market had overall. Its standard deviation at 6.38 per cent is, however, twice that of the equity REIT market portfolio at 3.12 per cent, which would indicate that the hotel REITs are riskier or more volatile than other equity REITs. On average, when compared to other equity REITs, hotel REITs performed better than diversified REITs ( 0.85 per cent), healthcare REITs ( 0.63 per cent), retail REITs ( 0.59 per cent) and specialty REITs ( 0.10 per cent $)$. During the study period, however, industrial REITs (1.28 per cent), mixed REITs (0.91 per cent), office REITs (1.08 per cent) and self-storage REITs (1.0 per cent) all had higher returns than hotel REITs. It is also interesting to note that hotel REITs had a higher standard deviation (6.38 per cent) than all equity REITs. This suggests that hotel REITs were riskier as investments than all other equity REITs. As expected, the 90-day treasuries, the proxy for the risk-free rate, had by far the lowest standard deviation at 0.14 per cent, but had the lowest average monthly return as well at 0.32 per cent. This indicated that they were less risky and had consistent, albeit lower, returns ( 0.32 per cent). In terms of the relevant 
Table 4: Descriptive statistics of monthly rate of return

\begin{tabular}{lllll}
\hline Sector & Mean (\%) & STD (\%) & Minimum (\%) & Maximum (\%) \\
\hline Hotel REIT & 0.89 & 6.38 & -26.41 & 26.27 \\
Diversified REIT & 0.85 & 3.33 & -10.81 & 14.03 \\
Healthcare REIT & 0.63 & 4.60 & -17.14 & 16.16 \\
Industrial REIT & 1.28 & 4.53 & -15.08 & 20.39 \\
Mixed REIT & 0.91 & 5.37 & -20.06 & 18.42 \\
Office REIT & 1.08 & 4.18 & -14.22 & 17.28 \\
Residential REIT & 0.93 & 3.82 & -7.06 & 31.36 \\
Retail REIT & 0.59 & 3.38 & -15.09 & 9.31 \\
Self-storage REIT & 1 & 3.94 & -16.60 & 12.10 \\
Specialty REIT & 0.10 & 4.94 & -14.26 & 15.75 \\
Equity REIT portfolio & 0.81 & 3.12 & -12.39 & 9.22 \\
S\&P 500 index & 0.76 & 4.11 & -14.58 & 9.67 \\
90-day treasuries & 0.32 & 0.14 & 0.07 & 0.53 \\
\end{tabular}

benchmark, hotel REITs on average performed better than S\&P 500 ( 0.76 per cent) but were riskier.

While the nonrisk-adjusted returns provided interesting information regarding the risk - return relationship, risk-adjusted analysis provides vastly greater insight into the overall structure of the various 'real' returns. As noted previously, the $\alpha$ 's and $\beta$ 's used in this analysis were estimated using the least-squares linear regression method, and the market portfolio or benchmark was represented by S\&P 500 index. In order to determine whether an individual sector REIT, or the REIT sector as a whole, had an excess return (either positive or negative), the $\alpha$ 's were tested to determine whether their values were statistically different from zero.

A statistically significant value different from zero implies that the particular REIT sector either overperformed or underperformed the particular market portfolio used (in this case S\&P 500). An $\alpha$ that was statistically significant and positive implied that the REIT overperformed the market portfolio and an $\alpha$ that was statistically significant and negative implied that the REIT underperformed the market portfolios.

Although all REIT sectors have $\alpha$ coefficients greater than zero (except specialty REITs, which were not statistically different than zero when testing), this may initially imply that they overperformed the market portfolio. Upon closer examination, however, we see that only industrial, office and self-storage REITs have $\alpha$ 's that are significant at the 0.05 level. This means that hotel, diversified, healthcare, mixed, residential, retail and specialty REITs all performed similar to the market portfolio on a risk-adjusted basis.

The $\beta$ 's tell us whether the particular REIT sector is riskier or less risky than the market portfolio. The $\beta$ 's were tested to see if statistically, they were significantly different than a value of one. A $\beta$ of one would imply that the particular REIT sector had a risk level approximately the same as the market portfolio; a $\beta$ greater than one would imply that the REIT sector was riskier than the market portfolio; and a $\beta$ less than one implies a REIT sector that is less risky than the market portfolio. Table 5 shows that all REIT sectors have $\beta$ 's that are significant at least at the 0.01 level. This would imply that all of the REIT sectors are statistically less risky than the market portfolio on a risk adjusted basis. While there was no 
Table 5: Performance of REITs sector relative to the S\&P500 using Jensen index - January 1993-December 2005

\begin{tabular}{|c|c|c|c|c|c|c|c|}
\hline \multicolumn{8}{|c|}{$(R i-R f)=\alpha+\beta(R m-R f)+\varepsilon$} \\
\hline $\begin{array}{l}\text { Dependent } \\
\text { variable }\end{array}$ & $\alpha($ coeff $)$ & $\alpha$ (t-stat) & $\beta$ (coeff) & $\beta$ (t-stat) & $R^{2}$ & F-Value & $\begin{array}{l}\text { Dubin } \\
\text { Watson }\end{array}$ \\
\hline Hotel REIT & 0.0033 & 0.679126 & 0.5414 & $-3.8938^{* * * *}$ & 0.1207 & 21.1309 & 1.923 \\
\hline Diversified REIT & 0.0045 & $1.70576 I^{*}$ & 0.1953 & $-12.6429^{* * * *}$ & 0.0576 & 9.4195 & 1.980 \\
\hline Healthcare REIT & 0.0021 & 0.574815 & 0.2318 & $-8.6499 * * *$ & 0.0423 & 6.8098 & 1.985 \\
\hline Industrial REIT & 0.0086 & $2.401099 * *$ & 0.2137 & $-8.9902^{* * * *}$ & 0.0373 & 5.9724 & 2.258 \\
\hline Mixed REIT & 0.0050 & 1.160329 & 0.2010 & 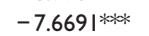 & 0.0236 & 3.7209 & 2.461 \\
\hline Office REIT & 0.0065 & $1.988662^{* * *}$ & 0.2454 & $-9.4522^{* * * *}$ & 0.0578 & 9.4452 & 2.236 \\
\hline Residential REIT & 0.0052 & $1.723269 *$ & 0.2045 & $-10.8387^{\text {**** }}$ & 0.0480 & 7.7589 & 2.193 \\
\hline Retail REIT & 0.0018 & 0.668687 & 0.2051 & -12.2256 **** & 0.0607 & 9.9519 & 2.154 \\
\hline Self-storage REIT & 0.0060 & $1.912137^{* * *}$ & 0.1891 & -10.6449 **** & 0.0385 & 6.1646 & 2.155 \\
\hline Specialty REIT & -0.0037 & -0.97385 & 0.3430 & $-7.0465^{* * * *}$ & 0.0808 & 13.5368 & 2.459 \\
\hline REIT portfolio & 0.0038 & 1.590234 & 0.2503 & $-12.8436^{* * * *}$ & 0.1067 & 18.3938 & 2.137 \\
\hline
\end{tabular}

$*, * *, * * *$ indicate significance at the 10,5 , and I per cent levels, respectively

REIT portfolio contains all ten sectors consisting of the 297 REITS included in the study

$F$-value's are all significant at the 0.001 level

evidence to suggest that the hotel REIT sector overperformed the market portfolio, there was evidence that other sectors did. Both diversified and residential were statistically significant at the 0.1 level and industrial, office and self-storage at the 0.05 level. Based on the results, there is no reason to believe that hotel REITs performed any better on a risk-adjusted basis than did the market portfolio. In summary, there is no reason to believe that the hotel REIT sector overperformed the market portfolio on a risk-adjusted basis. In essence, hotel REITs do not perform better or worse, statistically speaking, than the market portfolios.

\section{SUMMARY AND CONCLUSIONS}

Investment in REITs has become common in today's global investment marketplace. After almost 50 years in the US equity marketplace, the structure of REITs as a whole has evolved in large part due to direct government intervention via tax legislations. This structure has evolved and become more efficient from a management standpoint as well as from an investor's perspective. Hotel REITs have capitalised on this new structure and have become a dominant force in the US equity marketplace. Their prominence in the marketplace is seen in that, on average, hotel REITs had higher returns that the overall equity REIT market. Hotel REITs were found to be riskier than other equity REITs, however. This could be attributed to their relative 'newness' in the marketplace combined with the notion that the hotel industry is easily affected by events in the macroenvironment. Their relative newness could account for the fact that during the study period, on a risk-adjusted basis, hotel REITs did not perform better than the market portfolio. Another plausible explanation for this finding could be the fact that the performance of individual REITs is intricately linked to the performance of the underlying asset (Brounen et al., 2000). Hence, if hotels as a whole perform well, the corresponding hotel REIT will perform similarly. Conversely, if the hotel sector is not doing well, hotel REITs as a whole 
will not perform well. As noted previously, the study period was marked by economic volatility, highlighted specifically by two wars, economic recession, the SARs epidemic as well as the aftermath of September 11, 2001. These events all had a profound effect on the hotel industry and consequently the performance of hotel REITs. On the other hand, market composites such as S\&P 500 comprise a diversity of companies from various industries, many of which are recession resistant. Hence, it is not surprising that hotel REITs did not outperform the benchmark during the study period. The implication of this finding is that it behoves prudent and risk-averse hotel REIT investors to diversify the portfolio, since the hotel industry as a whole is not resistant to external events.

\section{Study limitations and suggestions for further research}

This study was limited by the fact that the universe of hotel REITs was confined to US hotel REITs. Hence, the generalisability of the findings may be limited. The present study focused on the structure of the US equity REIT industry and the performance of one key sub-sector of the industry — the hotel sector. Future studies could compare and contrast the REIT structures of the major global REITs. Such studies would provide interesting findings, especially for global real estate investors. In addition, future studies could examine and compare the performance of US hotel REITs and other REIT markets such as those in the United Kingdom, Canada, Germany, Japan and Australia. In addition, this study compared the performance of hotel REITs against one market benchmark. Future studies could utilise multiple benchmarks.

\section{References}

Beals, P. \& Arabia, J.V. (1998). Lodging REITs: Ready for an encore. Cornell Hotel and Restaurant Administration Quarterly. 39(6), 52-59.

Bergsman, S. (2001). REITs - Partner up with pension funds in joint ventures. Journal of Property Management. 66(5), 74-77.

Brounen, D.P., Eicholtz, M.A. \& Kanters, P.M. (2000). The effects of property development activities on the performance of REITs. Real Estate Finance. 16(4), 17-22.

Brueggerman, W.B. \& Fisher, J.D. (2005). Real Estate Finance and Investments, 12th edn, McGraw-Hill Irwin, New York.

Burch, K.R. \& Taylor, S.R. (1998). The internal conflicts of hotel REITs: Part I. Real Estate Review. 27(3), 10-19.

Busching, T. (2007). Germany enters the REIT universe with a big bang. Journal of Retail and Leisure Property. 6(3), 181-187.

Chan, K.C., Hendershott, P.H. \& Sanders, A.B. (1990). Risk and return on the real estate: Evidence from equity REITs. AREUEA Journal. 18, 431-452.

Chan, S.H., Erickson, J. \& Wang, K. (2003). Real Estate Investment Trusts: Structure, Performance, and Investment Opportunities, 1st edn, Oxford University Press, New York.

Chatrath, A. \& Liang, Y. (1998). REITs and inflation: A long-run perspective. Journal of Real Estate Research. 16(3), 311-325.

Chen, J. \& Peiser, R. (1999). The risk and return characteristics of REITs. Real Estate Finance. 16, 61-68.

Giliberto, S.M. (1990). Equity real estate investment trusts and real estate returns. Journal of Real Estate Research. 5, 259-263.

Glascock, J.L. \& Hughes, W.T. (1995). NAREIT identified exchange listed REITs and their performance characteristics: 1972-1991. Journal of Real Estate Literature. 3, 63-83.

Goebel, P.R. \& Kim, K.S. (1989). Performance evaluation of finite-life real estate investment trusts. Journal of Real Estate Research. 4, 57-69.

Gordon, S. \& McCarthy, W. (1998). Hotel REITS: The great disconnect. The Real Estate Finance Journal. 14(3), 59-64.

Grissom, T.V., Kuhle, J.L. \& Walther, C.H. (1978). Diversification work in real estate too. Journal of Portfolio Management. 5(2), 66-71. 
Gu, Z. \& Kim, H. (1998). Casino firm's risk features and their beta determinants. Progress in Tourism and Hospitality Research. 4, 357-365.

Gu, Z. \& Kim, H. (2003). An examination of the determinants of hotel REITs unsystematic risk. Journal of Hospitality \& Tourism Research. 27(2), 166-184.

Haddock, G. (1998). Today's REITs differ radically from their predecessors of 20 years ago - A premium choice. Journal of Accountancy. 185(3), 85-87.

Han, J. \& Liang, Y. (1995). The historical performance of real estate investment trusts. The Journal of Real Estate Research. 10(3), 235-262.

Howe, J.S. \& Shilling, J.D. (1990). REIT advisor performance. AREUEA Journal. 18, 479-500.

Imperiale, R. (2002). Real Estate Investment Trusts, 1st edn, John Wiley \& Sons, Inc., New York.

Jensen, M.C. (1968). The performance of mutual funds in the period 1945-1964. Journal of Finance. 23, 389-416.

Kim, H., Gu, Z. \& Mattila, A.S. (2002). Hotel real estate investment trusts' risk features and beta determinants. Journal of Hospitality \& Tourism Research. 26(2), 138-154.

Kim, H., Mattila, A.S. \& Gu, Z. (2002). Performance of hotel real estate investment trusts: A comparative analysis of Jensen indexes. International Journal of Hospitality Management. 21, 85-97.

Knight, R.A. \& Knight, L.G. (1993). REITs: An attractive investment vehicle. The CPA Journal. 63(4), 34-42.

Kuhle, J.L. (1987). Portfolio diversification and returns benefits - Common stock versus real estate investment trusts (REITs). Journal of Real Estate Research. 2, 1-19.

Kuhle, J.L., Walther, C.H. \& Wurtzebach, C.H. (1986). The financial performance of real estate investment trusts. The Journal of Real Estate Investment Trusts. 1(1), 67-75.

Li, Y. \& Wang, K. (1995). The predictability of REIT returns and market segmentation. Journal of Real Estate Research. 10(4), 471-482.

Martin, J.D. \& Cook, D.O. (1991). A comparison of the recent performance of publicly traded real property and portfolios and common stock. AREUEA Journal. 19, 184-212.

McMahan, J. (2006). The Handbook of Commercial Real Estate Investing, 1st edn, McGraw-Hill Irwin, New York.

Mueller, G.R. \& Anikeeff, M.A. (2001). Real estate ownership and operating businesses: Does combining them make sense for REITs? Journal of Real Estate Portfolio Management. 7(1), 55-65.

Mullaney, J.A. (1998). REITs: Building Profits with Real Estate Investment Trusts, 1st edn, John Wiley \& Sons, New York.

National Association of Real Estate Investment Trust, Inc (2008a). Historical index constituents, retrieved 26 January 2008, from http://www.nareit.com/library/domestic/companies.cfm.

National Association of Real Estate Investment Trusts, Inc (2008b). Historical REIT industry market capitalization: 1972-2007, retrieved 22 January 2008, from http://www.nareit.com/ industry/marketcap.cfm.

Oppenheimer, P. \& Grissom, T.V. (1998). Frequency space correlation between REITs and capital market indices. Journal of Real Estate Research. 16(3), 291-309.

Ori, J. (1995). A seven step portfolio diversification strategy. Real Estate Review. 12(4), 481-491.

Sagalyn, L.B. (1990). Real estate risk and the business cycle: Evidence from security markets. Journal of Real Estate Research. 5(2), 203-219.

Sanders, A.B. (1998). The historical behavior of REIT returns, in Garrigan, R. T. and Parsons, J. F. (eds.), Real Estate Investment Trusts, 1st edn, McGraw-Hill, New York, pp. 227-305.

Sarheim, G. (2006, April). REIT or Wrong, retrieved 27 May 2006, from http://www. hvsinternational.com.

Sharpe, W.F. (1966). Mutual fund performance. Journal of Business. 39(1), 119-138.

Smith, K.V. (1980). Historical Returns of Real Estate Equity Portfolios, 1st edn, Dow Jones-Irwin, Homewood, IL.

Smith, K.V. \& Schulman, D. (1976). The performance of equity real estate investment trusts. Financial Analysts Journal. 32, 61-66.

Smith Travel Research (2007). The Host Study: Hotel operating statistics report, The Host Study.

Titman, S. \& Warga, A. (1986). Risk and the performance of the real estate trusts: A multiple index approach. AREUEA Journal. 14(3), 414-431.

Treynor, J. (1965). How to rate management of mutual funds. Harvard Business Review. 8, 272-289.

Wang, K., Erickson, J., Gau, G. \& Chan, S.H. (1995). Market microstructure and real estate returns. Real Estate Economics. 23, 85-100.

Wang, K., Erickson, J., Gau, G. \& Chan, S.H. (1997). Market microstructure and real estate returns. Real Estate Economics. 23, 85-100.

Yobaccio, E., Rubens, J. \& Ketcham, D.C. (1995). The inflation-hedging properties of risk assets: The case of REITs. The Journal of Real Estate Research. 10(3), 279-296.

Zell, S. (1998). The REIT industry in the next four years: A glance around the corner. Real Estate Review. 28(4), 36-39. 